\title{
Comparative Susceptibilities of Legume Species to Infection by Phakopsora pachyrhizi
}

\author{
M. R. Bonde, S. E. Nester, D. K. Berner, and R. D. Frederick, United States Department of Agriculture- \\ Agricultural Research Service, Foreign Disease-Weed Science Research Unit, Fort Detrick, MD 21702; \\ W. F. Moore, Department of Entomology and Plant Pathology, Mississippi State University, Mississippi State \\ 39762; and S. Little, The Pictsweet Company, Bells, TN 38006
}

\begin{abstract}
Bonde, M. R., Nester, S. E., Berner, D. K., Frederick, R. D., Moore, W. F., and Little, S. 2008. Comparative susceptibilities of legume species to infection by Phakopsora pachyrhizi. Plant Dis. 92:30-36.

Knowledge of the host range of Phakopsora pachyrhizi is important to agriculture in the United States because of the distinct possibility that economic losses could occur to crops other than soybean. Furthermore, it is possible that alternative hosts could provide a means of overwintering of the pathogen, providing inoculum to initiate epidemics in future years. To clarify the potential importance of soybean rust on nonsoybean legumes and their role in overwintering of the disease, multiple accessions of clover, cowpea, pea, kudzu, lima bean, snap bean, and single accessions of coffee senna, Florida beggarweed, hemp sesbania, hyacinth bean, partridge pea, and showy crotalaria were inoculated under greenhouse conditions with urediniospores of $P$. pachyrhizi; infected soybean plants served as a control. The four criteria used to assess susceptibility were lesion density, proportion of lesions with sporulating uredinia, average number of uredinia per lesion, and average uredinia diameter, each determined 2 weeks following inoculation. Based on lesion densities, percentage of lesions with sporulation, and average numbers of uredinia per lesion, soybean, kudzu, and pea were the most susceptible species, followed by snap bean. However, because infected pea plants defoliated rapidly, urediniospore production presumably was limited, lessening the potential for epidemics on pea. Cultivars of snap bean produced numerous brown to reddish-brown lesions, many of which sporulated, but numbers of uredinia per lesion were lower than on soybean, kudzu, or pea. The presence of both tan (susceptible) and reddish-brown (resistant) lesions on kudzu demonstrated physiological differentiation on that host. Some kudzu plants appeared to be potentially excellent hosts for overwintering of the disease. The average number of uredinia per lesion appeared to be a valid measurement with which to compare host susceptibilities, and may have epidemiological significance. High susceptibility of a host was characterized by numerous uredinia with a wide range of sizes within individual lesions. In contrast, low susceptibility to rust was characterized by no or a few small uredinia.
\end{abstract}

Soybean rust, incited by Phakopsora pachyrhizi Syd. \& P. Syd., has been known in Asia for over 100 years, but was not detected in the continental United States until November 2004 (15). The first research on soybean rust in the United States began at the United States Department of Agriculture (USDA)-Agricultural Re-

Corresponding author: M. R. Bonde

E-mail: morris.bonde@ars.usda.gov

The use of trade, firm, or corporation names in this publication is for the information and convenience of the reader. Such use does not constitute an official endorsement or approval by the United States Department of Agriculture or the Agricultural Research Service of any product or service to the exclusion of others that may be suitable.

Accepted for publication 8 September 2007.

doi:10.1094/PDIS-92-1-0030

This article is in the public domain and not copyrightable. It may be freely reprinted with customary crediting of the source. The American Phytopathological Society, 2008. search Service Foreign Disease-Weed Science Research Unit (FDWSRU) in 1972 as part of a broader USDA program to prepare for the possible spread of threatening foreign plant pathogens to the United States (2). Research on soybean rust included assessment of the threat of the disease to U.S. agriculture, effects of temperature and moisture on disease development, detection and identification of the pathogen, screening germplasm for resistance, and delineation of the host range (2).

More than two decades before the arrival of soybean rust, Melching et al. (8) and Bromfield (2) were among the first to recognize the importance of alternative hosts for $P$. pachyrhizi in the United States. Although both teliospores and urediniospores had been reported to be produced by $P$. pachyrhizi (2), only the latter were known to infect plants $(2,8)$. Because urediniospores remain viable for only a few weeks, reinitiation of soybean rust in the absence of soybean following winter requires the reintroduction of the pathogen or existence of an infected alternative host (2). From such a host, the production of new urediniospores could initiate a rust epidemic if environmental conditions were suitable.

Of particular interest is kudzu, an extremely prolific legume weed in the southeastern United States (10). Survival of $P$. pachyrhizi mycelium in kudzu leaves presumably could allow overwintering of $P$. pachyrhizi and early sporulation the following spring. The predominant species in the United States is Pueraria montana (Lour.) Merr. var. lobata (Willd.) Maesen \& S.M. Almeida, and is referred to in this paper as U.S. kudzu because of the possibility that, in reality, it may constitute multiple species.

The broad host range for Phakopsora pachyrhizi is unusual for a rust pathogen. More than 95 legume species in over 42 genera have been reported susceptible to soybean rust $(2,13)$. However, it is difficult to assess the importance of many of these reported hosts because criteria used to determine whether a plant species was a host often were not given, and observations on sporulation not included. Without sporulation, an infected plant species contributes nothing to the dissemination of the pathogen and has negligible effect on the disease.

P. meibomiae, discovered on soybean in Puerto Rico in 1976, was thought at that time to be $P$. pachyrhizi (19). Not until 1992, however, did it become evident that two separate species of Phakopsora actually caused rust on soybean (Glycine max (L.) Merr.) (12). Because of the taxonomic confusion, host range reports for $P$. pachyrhizi from 1976 to the early 1990s must be considered carefully.

Melching et al. (8) in 1979 stated that "an analysis of the threat of rust to soybeans in the U.S. must await the results of other studies involving the potential host range and pathogen survival. It is a matter of record that soybean rust can increase and spread rapidly enough to cause substantial yield losses." This statement, written 25 years before the disease ever was discovered in the United States, is still true today.

The purposes of the research reported here were to further define the host range of $P$. pachyrhizi and to develop a means to compare host susceptibilities using important legume crops in the United States and 
legume species that might serve as a bridge for survival of $P$. pachyrhizi through winter months. Such information could help predict the severity of soybean rust in the United States and suggest where disease might be most severe.

\section{MATERIALS AND METHODS}

Pathogen isolate. The isolate of $P$. pachyrhizi used in our study was Brazil 01-1, a field collection of urediniospores from Parana, Brazil, collected in 2001 by J. T. Yorinori, EMBRAPA SOJA, Londrina, Brazil and sent to R. Frederick at the FDWSRU on infected leaves under the appropriate APHIS permit. At FDWSRU, the isolate was maintained on soybean $\mathrm{cv}$. Williams.

Urediniospores from greenhouse increases were collected from Williams soybean plants by means of a vacuum spore collection device (5) and stored in liquid nitrogen refrigerators at $-196^{\circ} \mathrm{C}$ until required for an experiment. Prior to each experiment, urediniospores were removed from storage, heat shocked at $40^{\circ} \mathrm{C}$ for 5 min, and hydrated overnight at $100 \% \mathrm{RH}$ over water in a closed container (1).

Legume accessions. Accessions of Dixie crimson clover (Trifolium incarnatum L.), Regal ladino white clover ( $T$. repens L.), Yuchi arrowleaf clover ( $T$. vesiculosum Savi), cowpea (Vigna unguiculata (L.) Walp.), lima bean (Phaseolus lunatus L.), pea (Pisum sativum L.), snap bean (Phaseolus vulgaris L.), coffee senna (Senna occidentalis (L.) Link), Florida beggarweed (Desmodium tortuosum (Sw.) DC.), hemp sesbania (Sesbania exaltata (Raf.) Rydb. ex A.W. Hill), hyacinth bean (Lablab purpureus (L.) Sweet), kudzu (Pueraria montana (Lour.) Merr. var. lobata (Willd.) Maesen \& S.M. Almeida), partridgepea (Cassia fasciculata (Michx.)
Greene), showy crotalaria (Crotalaria spectabilis Roth), and tropical kudzu ( $P$. phaseoloides Benth.) were used in the study. The soybean cv. Williams was used as a susceptible control in each experiment. Seed of all clover and weed accessions, except tropical kudzu, were provided by W. F. Moore and A. Rankins, Mississippi State University. Tropical kudzu seed, originally from Guatemala, was purchased from Kudzu Kingdom, Kodak, TN. Seed of cowpea, lima bean, pea, and snap bean were provided by $\mathrm{S}$. Little, The Pictsweet Company, Bell, Tennessee.

Plant propagation. Seed of commercial cultivars and hyacinth bean had high germination rates and required no special treatment. They were planted directly into a standard FDWSRU greenhouse soil mix, containing a peat and compost-based mix $(60 \%)$, coarse perlite $(24 \%)$, coarse ver-
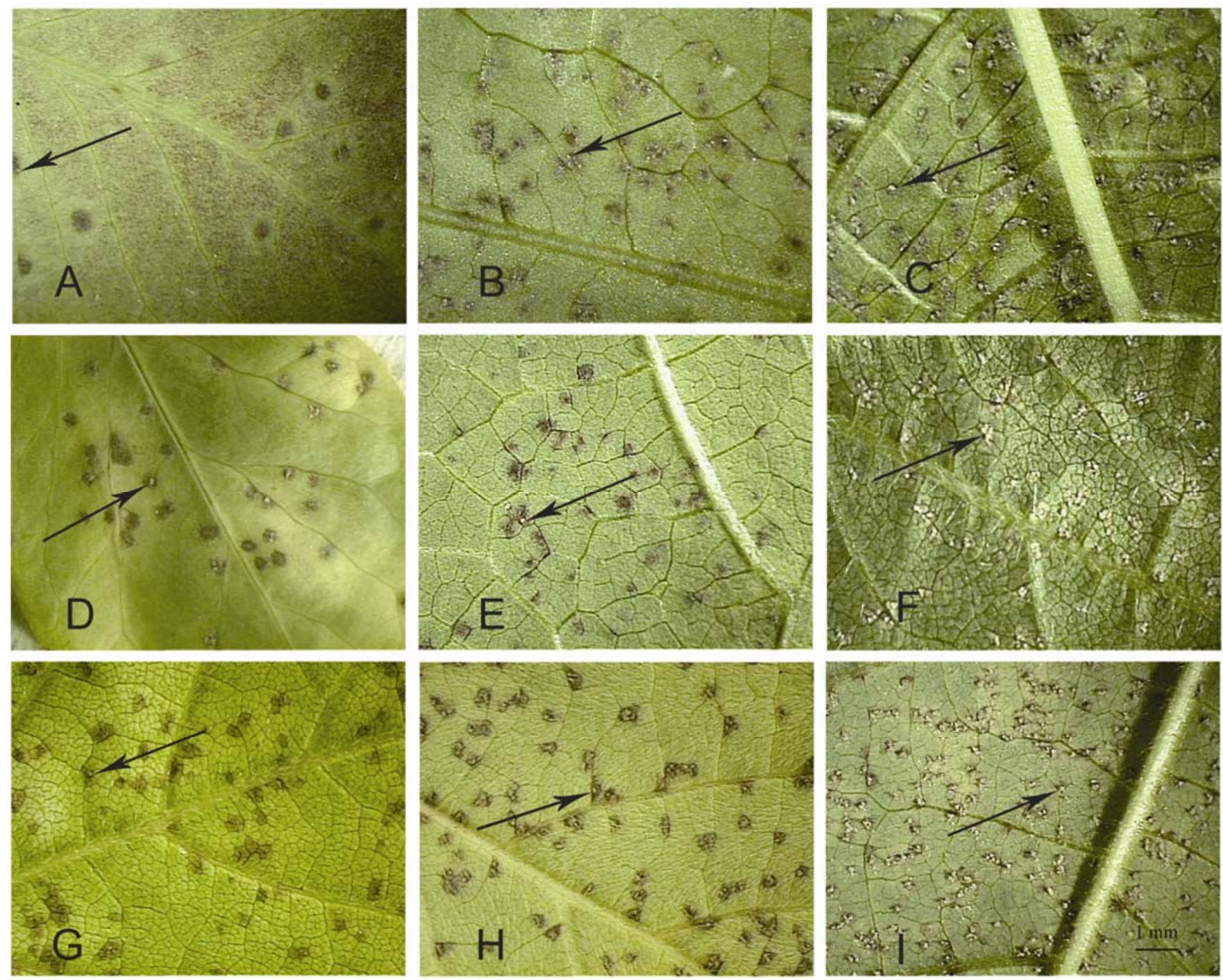

Fig. 1. Representative symptoms on infected leaves 14 days after inoculation. A, Lesions on Dixie Crimson clover with very little sporulation; B, lesions on cowpea with small amount of sporulation; $\mathbf{C}$, typical lesions on snap bean with sporulation in most lesions; $\mathbf{D}$, lesions on pea with clusters of uredinia in lesions; E, typical reddish-brown (RB) lesions on lima bean with little sporulation, $\mathbf{F}$, typical tan (Tan) lesions on cv. Williams soybean with high sporulation; G, RB lesions on tropical kudzu (Pueraria phaseoloides) with no sporulation; H, Tan lesions with moderate amounts of sporulation on a U.S. accession of kudzu (P. montana var. lobata); I, Tan lesions on U.S. kudzu with heavy sporulation. Representative areas with sporulation are indicated by arrows. The 1$\mathrm{mm}$-size marker at the lower right applies to all photographs in the composite. 
miculite (8\%), sand (8\%), and 10-10-10 fertilizer, lime, trace minerals, and a wetting agent, in $10.2-\mathrm{cm}$-diameter clay pots. Seed of some weed species, however, required special treatment to obtain germination levels sufficient for experiments.

Kudzu seed were germinated by soaking in $0.525 \%$ sodium hypochlorite for $5 \mathrm{~min}$, incubating overnight on wet filter paper in a petri dish at $30^{\circ} \mathrm{C}$, nicking with a razor blade, and incubating on the filter paper up to an additional 11 days at $30^{\circ} \mathrm{C}$ with a $15-$ $\mathrm{h}$ day length (18). Germinated seed were planted in wet vermiculite and, when of sufficient size, transferred to soil in 10.2cm-diameter clay pots.

Seed of showy crotalaria were scarified between two pieces of sandpaper, soaked overnight in aerated gibberellic acid at 100 ppm, and incubated on moist filter paper in petri dishes (4). Seed of Florida beggarweed were soaked for $10 \mathrm{~min}$ in concentrated $\mathrm{H}_{2} \mathrm{SO}_{4}$, rinsed, and then placed on moist filter paper at $30^{\circ} \mathrm{C}$ (4). Seed of partridge pea and hemp sesbania were scarified, and seed of coffee senna were ruptured by compression with a rolling pin, before placing on filter paper wet with a solution of gibberellic acid at $100 \mathrm{ppm}$ and incubating at $22^{\circ} \mathrm{C}$, a modification of a previously described method (4). Seedlings of each species were transplanted to soil in $10.2-\mathrm{cm}$ clay pots.

Inoculation of most species was done 4 to 6 weeks after planting. Kudzu, however, required approximately 12 weeks to attain sufficient size.

Plant inoculation. Inoculations were done in the BioSafety level-3 plant pathogen containment facility at FDWSRU (9) by spraying plants to run-off with a suspension of $2.5 \times 10^{4}$ urediniospores $/ \mathrm{ml}$ of distilled water containing 1 drop of Tween 20 per $100 \mathrm{ml}$. Inoculated plants then were incubated overnight in dew chambers at $20^{\circ} \mathrm{C}$, then placed on a greenhouse bench at 20 to $25^{\circ} \mathrm{C}$, with $16 \mathrm{~h}$ supplemental lighting per day from 1,000-W Metalarc high-intensity lamps (Sylvania, Danvers, MA). The experiment was conducted twice. In each experiment, all commercial cultivars and hyacinth bean were inoculated on a single day. Florida beggarweed, coffee senna, hemp sesbania, U.S. kudzu, tropical kudzu, partridge pea, showy crotalaria, and hyacinth bean were inoculated on a second day. For each inoculation, Williams soybean was included as a control.

Lesion types, density, and sporulation. Two weeks after inoculation, representative leaves on three inoculated plants, or groups of plants in separate pots for clover, were examined to determine lesion reaction type, relative lesion densities, and percentage of lesions sporulating. Lesion types were classified as "Tan," "RB," or "Mixed" as previously described for soybean $(1,2)$. "Tan" indicated that lesions were tan and "RB" that lesions were reddish brown in color. "Mixed" reactions had a mixture of Tan and RB lesions on the same leaf. Reaction designations were based solely on lesion color, although Tan lesions characteristically had numerous urediniospores and RB lesions had few. Photographs of infected leaves were taken at $\times 7$ magnification with a digital camera (Nikon Digital Sight DS-Ll) mounted on an Olympus SZX12 dissecting microscope, which allowed reexamination of symptoms at a later date.

Lesion density on each of the three plants was rated on a five-point scale as previously described (11), in which $1=$ no lesions, $2=\mathrm{a}$ few lesions, $3=\mathrm{a}$ moderate lesion density, 4 = a heavy lesion density, and $5=$ a very heavy lesion density equal to that on soybean. Soybean was used as the susceptible standard and given the maximum rating of 5 for each inoculation in each experiment. The relative percentage of lesions producing urediniospores on each of the three plants was rated on a 0 to- 5 scale in which $0=$ no sporulation, $1=$ $20 \%, 2=40 \%, 3=60 \%, 4=80 \%$, and $5=$ $100 \%$ of the lesions sporulating.

Data were combined from the two experiments (total $n=6$ ) to determine average ratings for lesion densities, proportion of lesions sporulating, and standard errors of the means, and analyzed statistically as described below.

Uredinia numbers and diameters. Immediately after examination of living plants for lesion density, sporulation, and reaction type, leaflets with symptoms were excised from the plants and placed in Farmer's solution (2:1 absolute ethanol:acetic acid) for at least $24 \mathrm{~h}$ to fix the tissue, submerged $24 \mathrm{~h}$ in lactophenol to remove leaf pigments, and stained overnight in lactophenol containing $0.1 \%$ cotton blue (1). Excess stain was removed from the surface of leaflets by briefly rinsing in lactophenol. The leaflets were mounted by placing them on a pool of lactophenol in an inverted petri dish lid, placing additional drops of lactophenol on the surface of the leaflets by means of a Pasteur pipette, and then placing a petri dish bottom into the lid to sandwich the sample, surrounded by lactophenol, between the two pieces of plastic.

The leaflets were observed microscopically as whole-leaf mounts at $\times 15$ magnification to determine the numbers of uredinia per lesion for each host accession, and at $\times 90$ to measure the diameters of uredinia by means of an ocular micrometer. Data were collected from 50 randomly selected lesions for each host accession in each experiment, and data combined for the two experiments (total $n=100$ ) to determine average numbers of uredinia per lesion and standard errors of the means. In order to compare numbers of uredinia per lesion for soybean, cowpea, snap bean, pea, lima bean, and kudzu, data were combined within species to determine overall mean numbers of uredinia per lesion.
In all, 50 representative isolated uredinia (fewer, if 50 were not available) for each host accession in each of two experiments were measured at $\times 90$ by means of an ocular micrometer, data for each accession combined from the two experiments, and average uredinia diameters calculated. Digital images with and without uredinia were recorded by means of a Nikon Digital Sight DS-1 camera mounted on an Olympus SZX12 dissecting microscope for later comparisons.

Statistical analyses. Data for the continuous variables, number of uredinia per lesion and uredinia diameter, were analyzed as a nested design with accessions nested within plant type (usually equal to plant species). Analysis of variance was done using the Mixed procedure of Statistical Analysis System (SAS, version 9.1; SAS Institute, Cary, NC), with plants and accessions within plants as fixed effects. Least squares means for plants and accessions were generated along with probabilities of differences among them. Lettered groupings of differences in these least squares means were generated using a SAS macro written by A. M. Saxton (14; available from http://animalscience.ag.utk.edu/ faculty/saxton/software.htm).

Ordinal data from the rating scales for sporulation and lesion density were ranked using the Rank procedure of SAS. The ranks were analyzed by analysis of variance using the Mixed procedure with the anovaf option, according to the method described by Brunner et al. (3) and Shah and Madden (16) for nonparametric analysis of ordinal data, to generate $F$ tests for plant types (plant species) and accessions within plant types. The rating scale data then were analyzed using the SAS program written by Brunner et al. (3) (available from http://www.ams.med.uni-goettingen. de/Projekte/LD/Makros_LD.html), which converts the rating scales to ranks and generates relative effects $([1 / \mathrm{N}] \times[$ mean rank $-1 / 2])$ and associated variances. If $F$ tests for plant type and accession within plant type were significant, then comparisons of relative effects among plant types and accessions within plant types were done with pairwise $t$ tests for each pair of plant types or accessions within plant types. This was done by calculating a least significant difference (LSD) for each comparison, where LSD $=$ (tabulated $t$ value at $P=0.05$ and error degrees of freedom $=$ $132) \times($ square root [variance $1 /$ sample size $1+$ variance $2 /$ sample size 2$]$ ).

\section{RESULTS}

Lesion types, densities, and sporulation. Examples of typical lesions are shown in Figure 1. On soybean, lesions were tan colored and abundant (Fig. 1F). Necrosis was minimal, distinguishing it from the other hosts.

Lesions on infected pea were brown, moderately numerous, with a high propor- 
tion sporulating (Fig. 1D). Peculiar to pea was a rapid defoliation.

Cowpea had moderately high densities of brown to black lesions with little or no apparent sporulation (Figs. 1B). Placement of infected plants in a moist tent for 14 days after inoculation did not increase sporulation.

Snap bean produced moderate to high numbers of RB lesions, with easily visible sporulation (Fig. 1C), whereas lima bean produced moderate to high numbers of lesions which rarely sporulated (Fig. 1E). No lesions were observed on two of three clover accessions evaluated. Dixie Crimson produced a few nonsporulating lesions in one of two experiments (Fig. 1A).

Tropical kudzu and hyacinth bean both produced numerous lesions, whereas Florida beggarweed, coffee senna, hemp sesbania, partridgepea, and showy crotalaria produced few lesions. Of those that sporulated, tropical kudzu and hyacinth bean had sporulation ratings of 1 and hemp sesbania had a rating of 2 .

U.S. kudzu produced high numbers of lesions (Fig. 1I; Table 1). Three plants produced only Tan lesions and were desig- nated "Tan" (Fig. 1I), and five produced mixtures of Tan and RB lesions, designated "Tan/RB". Plants with mixtures of lesion types produced more Tan than RB lesions. Plants with only Tan lesions had nearly $100 \%$ lesions sporulating, whereas plants with mixtures had 20 to $100 \%$ (average $83 \%$ ) lesions sporulating, based on conversion of sporulation ratings to percentages.

For sporulation, $F$ tests were highly significant for both plant types and accessions within plant types. Relative effects for these variables are presented in Table 1. Larger relative effects reflect higher ratings

Table 1. Means for number of uredinia per lesion, uredinia diameter, and relative effects for sporulation and lesion density for plant types (species) and accessions (cultivars) within plant types ${ }^{\mathrm{y}}$

\begin{tabular}{|c|c|c|c|c|}
\hline \multirow[b]{2}{*}{ Plant accession } & \multicolumn{2}{|c|}{ Means } & \multicolumn{2}{|c|}{ Relative effects $^{\mathbf{z}}$} \\
\hline & No. of uredinia per lesion & Uredinia diameter & Sporulation & Lesion density \\
\hline \multicolumn{5}{|l|}{ Cowpea } \\
\hline Top Pinkeye & $0.15 \mathrm{NS}$ & $73.00 \mathrm{~B}$ & $0.28 \mathrm{BC}$ & $0.11 \mathrm{~B}$ \\
\hline Pinkeye Bur & $0.53 \mathrm{NS}$ & $110.50 \mathrm{~A}$ & $0.45 \mathrm{~A}$ & $0.63 \mathrm{~A}$ \\
\hline Coronet & $0.15 \mathrm{NS}$ & $104.00 \mathrm{AB}$ & $0.41 \mathrm{AB}$ & $0.61 \mathrm{~A}$ \\
\hline Charleston Green Pak & $0.27 \mathrm{NS}$ & $105.00 \mathrm{~A}$ & $0.34 \mathrm{BC}$ & $0.50 \mathrm{AB}$ \\
\hline Mississippi Silver & $0.00 \mathrm{NS}$ & $\ldots$ & $0.19 \mathrm{C}$ & $0.16 \mathrm{~B}$ \\
\hline White Acre & $0.05 \mathrm{NS}$ & $87.00 \mathrm{AB}$ & $0.23 \mathrm{BC}$ & $0.34 \mathrm{AB}$ \\
\hline Plant mean & $0.19 \mathrm{D}$ & $95.90 \mathrm{D}$ & $0.32 \mathrm{D}$ & $0.39 \mathrm{D}$ \\
\hline \multicolumn{5}{|l|}{ Green pea } \\
\hline Austrian Winter & $6.35 \mathrm{~A}$ & $120.00 \mathrm{NS}$ & $0.68 \mathrm{NS}$ & $0.31 \mathrm{NS}$ \\
\hline Early Freezer 680 & $3.20 \mathrm{~B}$ & $121.50 \mathrm{NS}$ & $0.86 \mathrm{NS}$ & $0.30 \mathrm{NS}$ \\
\hline Genie & $1.02 \mathrm{C}$ & $103.00 \mathrm{NS}$ & $0.51 \mathrm{NS}$ & $0.28 \mathrm{NS}$ \\
\hline Bolero & $4.25 \mathrm{~B}$ & $116.00 \mathrm{NS}$ & $0.86 \mathrm{NS}$ & $0.34 \mathrm{NS}$ \\
\hline Plant mean & $3.71 \mathrm{~A}$ & 115.13 ABC & 0.74 B & 0.31 E \\
\hline \multicolumn{5}{|l|}{ Lima bean } \\
\hline Henderson & $0.00 \mathrm{NS}$ & $\ldots$ & $0.19 \mathrm{NS}$ & $0.35 \mathrm{NS}$ \\
\hline C-elite & $0.00 \mathrm{NS}$ & $\ldots$ & $0.19 \mathrm{NS}$ & $0.42 \mathrm{NS}$ \\
\hline $184-85$ & $0.00 \mathrm{NS}$ & $\ldots$ & $0.19 \mathrm{NS}$ & $0.61 \mathrm{NS}$ \\
\hline Jackson Wonder & $0.05 \mathrm{NS}$ & $93.00 \mathrm{NS}$ & $0.19 \mathrm{NS}$ & $0.36 \mathrm{NS}$ \\
\hline White Dixie & $0.01 \mathrm{NS}$ & $112.00 \mathrm{NS}$ & $0.28 \mathrm{NS}$ & $0.41 \mathrm{NS}$ \\
\hline Cypress & $0.00 \mathrm{NS}$ & $\ldots$ & $0.19 \mathrm{NS}$ & $0.30 \mathrm{NS}$ \\
\hline Fordhook Conc. & $0.04 \mathrm{NS}$ & $112.00 \mathrm{NS}$ & $0.32 \mathrm{NS}$ & $0.65 \mathrm{NS}$ \\
\hline Plant mean & 0.01 D & 105.67 BCD & $0.22 \mathrm{E}$ & $0.44 \mathrm{C}$ \\
\hline \multicolumn{5}{|l|}{ Snap bean } \\
\hline Contender & $0.50 \mathrm{NS}$ & $104.50 \mathrm{NS}$ & $0.55 \mathrm{NS}$ & $0.38 \mathrm{NS}$ \\
\hline Roma II & $1.53 \mathrm{NS}$ & $111.00 \mathrm{NS}$ & $0.79 \mathrm{NS}$ & $0.56 \mathrm{NS}$ \\
\hline Masai & $0.70 \mathrm{NS}$ & $101.50 \mathrm{NS}$ & $0.70 \mathrm{NS}$ & $0.66 \mathrm{NS}$ \\
\hline Tapio & $2.15 \mathrm{NS}$ & 104.00 NS & $0.58 \mathrm{NS}$ & $0.60 \mathrm{NS}$ \\
\hline Labrador & $0.75 \mathrm{NS}$ & 107.00 NS & $0.50 \mathrm{NS}$ & $0.43 \mathrm{NS}$ \\
\hline Caprice & $1.90 \mathrm{NS}$ & $105.00 \mathrm{NS}$ & $0.79 \mathrm{NS}$ & $0.70 \mathrm{NS}$ \\
\hline Minuette & $1.80 \mathrm{NS}$ & $111.50 \mathrm{NS}$ & $0.75 \mathrm{NS}$ & $0.69 \mathrm{NS}$ \\
\hline Plant mean & $1.33 \mathrm{C}$ & 106.43 CD & $0.66 \mathrm{C}$ & 0.57 B \\
\hline \multicolumn{5}{|l|}{ Soybean } \\
\hline Williams & 4.85 & 133.50 & 0.86 & 0.78 \\
\hline Plant mean & $4.85 \mathrm{~A}$ & 133.50 A & $0.86 \mathrm{~A}$ & $0.78 \mathrm{~A}$ \\
\hline \multicolumn{5}{|l|}{ Tan Kudzu } \\
\hline B & $2.80 \mathrm{NS}$ & $123.00 \mathrm{NS}$ & $0.86 \mathrm{NS}$ & $0.88 \mathrm{NS}$ \\
\hline $\mathrm{C}$ & $3.80 \mathrm{NS}$ & $118.00 \mathrm{NS}$ & $0.86 \mathrm{NS}$ & $0.88 \mathrm{NS}$ \\
\hline $\mathrm{J}$ & $2.60 \mathrm{NS}$ & $129.00 \mathrm{NS}$ & $0.86 \mathrm{NS}$ & $0.88 \mathrm{NS}$ \\
\hline Plant mean & 3.07 AB & 123.33 AB & 0.86 A & 0.88 A \\
\hline \multicolumn{5}{|c|}{ Tan/Reddish-Brown Kudzu } \\
\hline $\mathrm{D}$ & $2.33 \mathrm{NS}$ & $109.00 \mathrm{NS}$ & $0.80 \mathrm{NS}$ & $0.61 \mathrm{NS}$ \\
\hline $\mathrm{E}$ & $3.50 \mathrm{NS}$ & $112.00 \mathrm{NS}$ & $0.80 \mathrm{NS}$ & $0.79 \mathrm{NS}$ \\
\hline $\mathrm{G}$ & $0.60 \mathrm{NS}$ & $89.00 \mathrm{NS}$ & $0.51 \mathrm{NS}$ & $0.88 \mathrm{NS}$ \\
\hline $\mathrm{H}$ & $2.40 \mathrm{NS}$ & $122.00 \mathrm{NS}$ & $0.77 \mathrm{NS}$ & $0.88 \mathrm{NS}$ \\
\hline I & $0.90 \mathrm{NS}$ & $99.00 \mathrm{NS}$ & $0.77 \mathrm{NS}$ & $0.88 \mathrm{NS}$ \\
\hline & $1.93 \mathrm{BC}$ & 106.20 BCD & 0.75 AB & 0.78 A \\
\hline \multicolumn{5}{|l|}{ Tropical Kudzu } \\
\hline A & 0.64 & 37.00 & 0.32 & 0.75 \\
\hline Plant mean & 0.64 BCD & $37.00 \mathrm{E}$ & 0.322 ABCDE & 0.75 ABCDE \\
\hline
\end{tabular}

y NS = not significant at $P \leq 0.05$. Means in a column followed by the same letter are not significantly different at $P \leq 0.05$. Plant means and letter groupings in bold type are for comparisons among the plant types. Plant means in a row followed by the same letter are not significantly different at $P \leq 0.05$.

${ }^{\mathrm{z}}$ Relative effects and their variances were computed from ranks of ordinal rating scales according to the methods of Brunner et al. (3) and Shah and Madden (16) using SAS programming code developed by these authors. Larger relative effects reflect higher ratings for sporulation $(0$-to- 5 rating scale, with $0=$ no sporulation and $5=100 \%$ sporulation) and lesion density ( 1 -to-5 rating scale, with $1=$ no lesions and $5=$ heavy lesion density). 
for sporulation and lesion density. There were significant differences in relative effects for sporulation among plant types. Soybean and both types of U.S. kudzu had significantly more sporulation (greater relative effects for sporulation) than cowpea, lima bean, and snap bean. Lima bean, tropical kudzu, and cowpea had the lowest sporulation; however, because of a large variance, the relative effect for tropical kudzu was not significantly different from other plant types. There were significant differences in relative effects among accessions within plant types only for cowpea. The cowpea cvs. Charleston Green Pak, Coronet, and Pinkeye Bur had the highest sporulation and, conversely, cvs. Mississippi Silver, Top Pinkeye, and White Acre had the lowest sporulation (Table 1).

For lesion densities, $F$ tests were highly significant $(P<0.01)$ for plant types and significant at $P=0.02$ for accessions within plant types. There were significant differences in relative effects among plant types (Table 1). Soybean and both types of U.S. kudzu had significantly greater lesion density than cowpea, lima bean, snap bean, and green pea. Because of a large variance, the relative effect for tropical kudzu was not significantly different from other plant types. Although tropical kudzu had relatively high lesion density, there was little sporulation (Table 1). Conversely, pea had relatively low lesion density but high sporulation. There were significant differences in relative effects among accessions within plant types only for cowpea. Cowpea cvs. Charleston Green Pak, Coronet, and Pinkeye Bur had the highest lesion densities and Mississippi Silver, Top Pinkeye, and White Acre had the lowest lesion densities (Table 1).

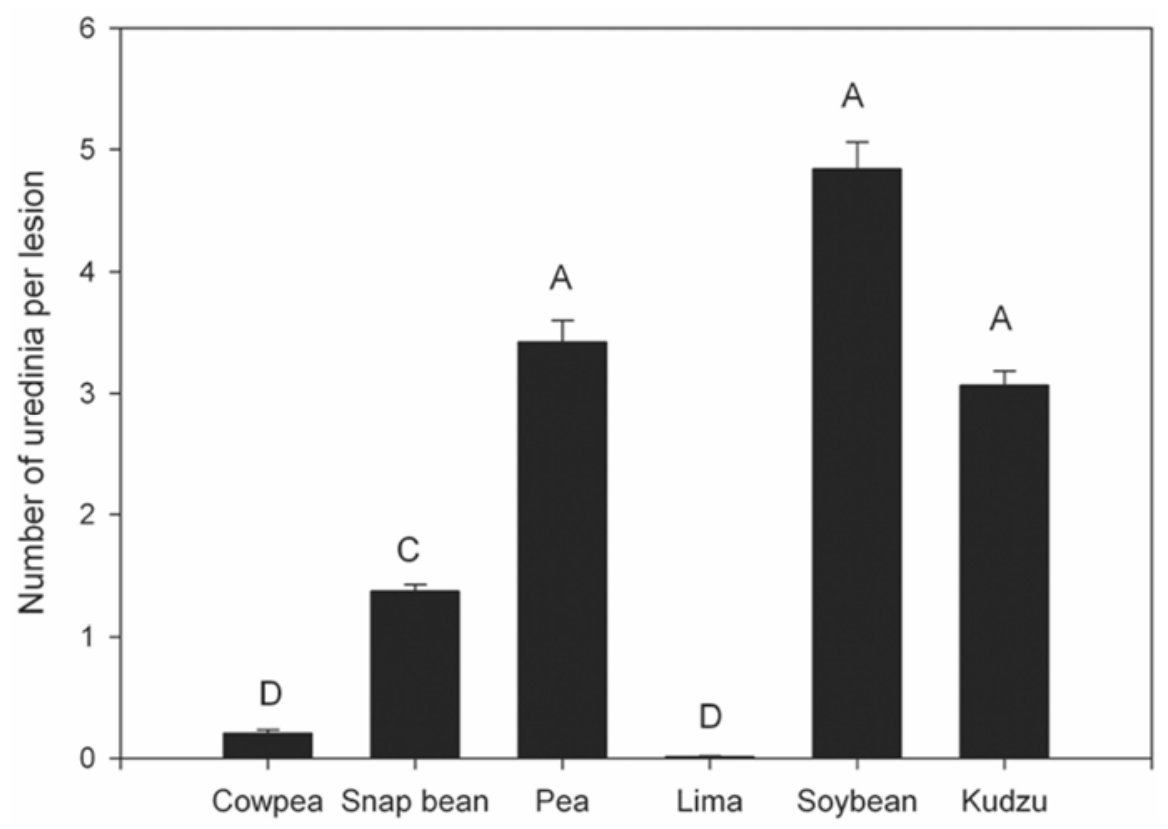

Fig. 2. Average numbers of uredinia per lesion for cowpea, snap bean, pea, lima bean, cultivar Williams soybean, and susceptible kudzu. Data were combined for each group to determine overall means and standard errors of the means. Bars with the same letter are not significantly different at $P \leq 0.05$. later a mixture of susceptible and resistant reaction types.

Typical reactions to Phakopsora pachyrhizi, as observed within stained leaflets, are shown in Figure 3. A highly susceptible reaction was typified by numerous uredinia varying in size within a lesion (Fig. 3D, F, and I); resistant reactions were typified by few or no uredinia (Fig. 3A, B, E, and G). The differences were so apparent that resistance often could be recognized almost immediately upon microscopic examination of stained leaf tissue. In some instances, resistance was associated with a brown to reddishbrown reaction that could be described as a hypersensitive response (Fig. 3B, C, G, and $\mathrm{H}$ ). Mixtures of Tan and RB lesions were common on some kudzu and snap bean accessions (Fig. 3C and $\mathrm{H}$ ).

\section{DISCUSSION}

Selection of each species to be included in our study was based on relative importance as a legume crop in the United States or as a plant species most likely to provide a means for survival of $P$. pachyrhizi through winter months in the southeastern United States.

The numbers of uredinia per lesion, average uredinia diameters, lesion densities, and percentages of lesions sporulating each presumably could be used to measure and compare susceptibilities of infected hosts. The large number of uredinia of varying size in highly susceptible reactions almost certainly resulted from continued development of the pathogen over an extended period of time, resulting in uredinia of different maturities and, consequently, different sizes. In contrast, the pathogen in resistant reactions was restricted, leading to few uredinia, all of which remained small. Similar differences were reported on soybean (1). The recognition of resistance or susceptibility based on uredinia numbers and sizes is quick, accurate, and highly quantitative.

Physiological specialization in soybean infected by $P$. pachyrhizi has been known for several decades (2), and four major resistance genes identified $(1,2,11)$. The isolate we used in this study, Brazil 01-1, is known to produce mixtures of reaction types on individual soybean plants, indicating that the isolate comprises a mixture of virulence phenotypes (1). For the host range study presented here, the broad range of pathogen biotypes was desirable, giving a greater chance of detecting susceptible reactions in nonsoybean legumes. Because kudzu, Pueraria montana var. lobata, is known to be genetically diverse (17) and, like soybean, has its origin in Asia (17), the presence of physiological specialization is not unexpected. Indeed, races of Phakopsora pachyrhizi have been suggested to exist on kudzu in Japan (20).

Except for kudzu, the reactions of "weeds" tested demonstrated a lack of or 
low susceptibility to $P$ pachyrhizi. Of the crops we tested, clovers, grown over immense agricultural areas of the United States, also were, at most, poor hosts for $P$. pachyrhizi. Only Crimson clover produced any lesions, and sporulation was, at best, sparse. Cowpea produced numerous lesions but sporulation was sparse and, therefore, the crop was considered to be a poor host.

Pea was moderately susceptible to soybean rust, producing a moderate number of lesions and supporting the formation of numerous uredinia (Table 1; Fig. 3D). Infected leaves, however, defoliated rapidly. This suggested that urediniospore production under field conditions might be of short duration. Although concentrated inoculum arriving in a pea field possibly could cause significant initial infection, it remains unknown if the pathogen would spread and pea suffer yield loss.
The genus Phaseolus was of particular interest because it comprises several important food crops. Although it was apparent that lima bean was not very susceptible to $P$. pachyrhizi, infected snap bean produced numerous lesions, and several cultivars sporulated well. Higher numbers of uredinia per lesion were observed on $\mathrm{Ca}$ price, Minuette, Roma II, and Tapia than on the other snap bean cultivars; however, the differences were not significant (Table 1).

The lower numbers of uredinia per lesion on snap bean compared with soybean indicated less susceptibility to rust (Table 1). In South Africa, dry bean (Phaseolus vulgaris) infected with Phakopsora pachyrhizi were discovered in the field (6), and the disease recently was found on scarlet runner bean (Phaseolus coccineus L.), lima bean, and red kidney bean ( $P$. vulgaris) in the United States (7). The demonstrated susceptibility of Phaseolus spp. to soybean rust in the field suggests that this species should continue to be monitored and, if disease is found, crop loss studies conducted.

Of the limited legume species we tested, kudzu, soybean, and pea were the most susceptible. Given the artificial conditions for this study, however, we recognize that results in the field might be different.

The development of a soybean rust epidemic in the United States leading to significant disease losses will depend on several factors, beginning with the need to have good urediniospore production on an overwintering host, survival of the urediniospores during long-distance transport, and an environment suitable for disease initiation and development once the spores arrive at a site with susceptible plants. Knowledge of what plant species are susceptible will help determine the long-term threat of the disease.
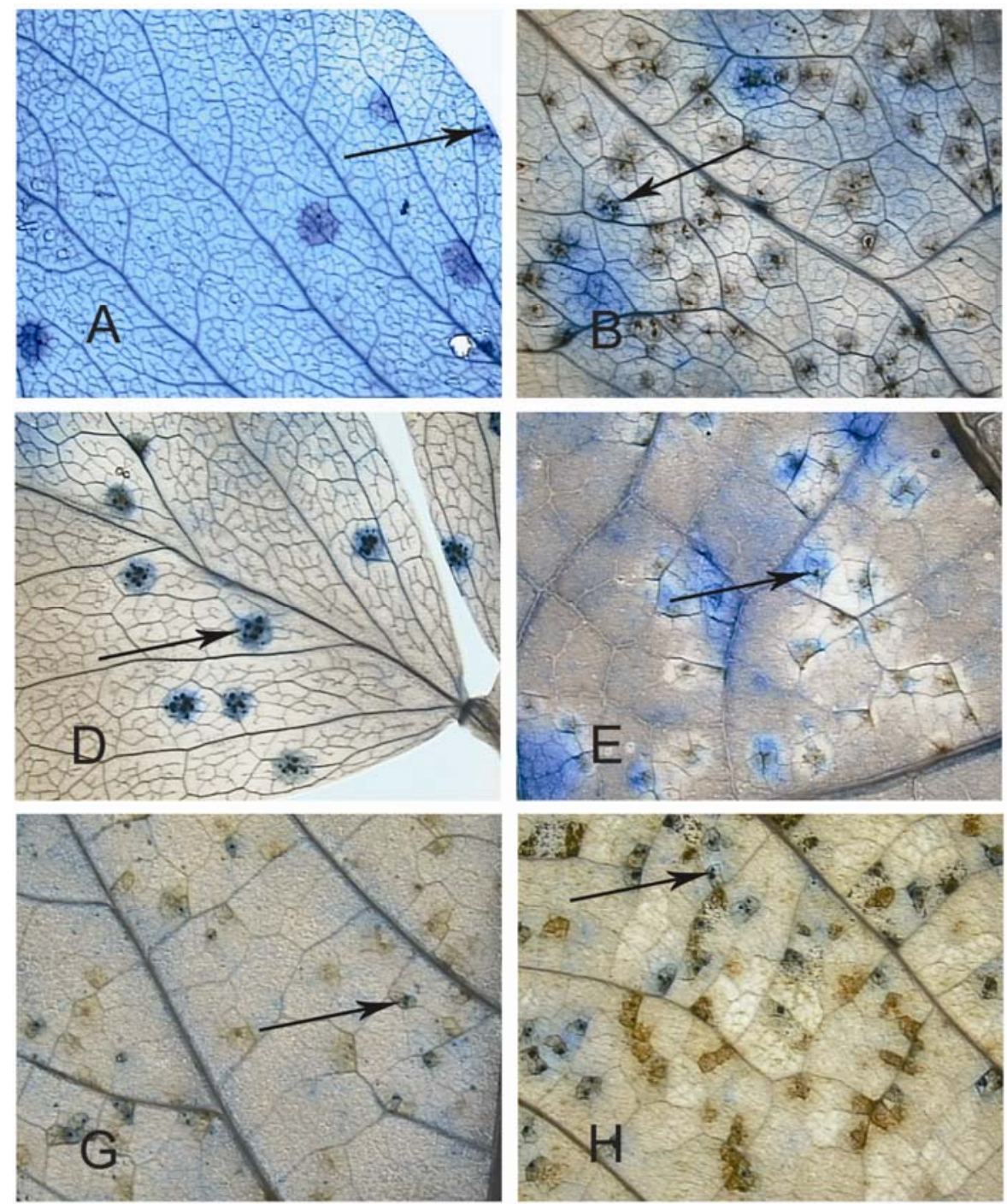

Fig. 3. Typical uredinia in leaves of infected legume accessions fixed, cleared, and stained with cotton blue. A, Clover; B, cowpea; C, snap bean with high proportion of lesions sporulating; $\mathbf{D}$, pea with numerous uredinia that vary in size within each lesion, indicating high susceptibility to soybean rust; $\mathbf{E}$, brown lesions on lima bean, with a small amount of sporulation; F, cv. Williams soybean, highly susceptible to soybean rust, with several uredinia varying in size within each lesion; G, brown lesions on tropical kudzu, few uredinia present; H, mixture of reddish-brown (resistant) and tan (Tan; susceptible) lesions on U.S. kudzu accession; and I, Tan lesions on a U.S. accession of kudzu with uredinia present in all lesions. Uredinia for A through I are indicated by arrows. The 1-mm-size marker at the lower right applies to all photographs in the composite. 
Phakopsora pachyrhizi, being an obligate pathogen, requires a living host. Presently, kudzu is the only known host that could provide large amounts of living tissue for overwintering of $P$. pachyrhizi in the southeastern United States in areas where the host does not freeze. A detailed study to determine the role of kudzu in soybean rust epidemiology should be a priority of soybean rust research in the United States.

\section{ACKNOWLEDGMENTS}

We thank H. Tipton for excellent technical assistance in conducting the studies described in this manuscript.

\section{LITERATURE CITED}

1. Bonde, M. R., Nester, S. E., Austin, C. N., Stone, C. L., Frederick, R. D., Hartman, G. L., and Miles, M. R. 2006. Evaluation of virulence of Phakopsora pachyrhizi and P. meibomiae isolates. Plant Dis. 90:708-716.

2. Bromfield, K. R., 1984. Soybean Rust. Mongr. No. 11. American Phytopathological Society, St. Paul, MN.

3. Brunner, E., Domhof, S., and Langer, F. 2002. Nonparametric Analysis of Longitudinal Data in Factorial Experiments. John Wiley \& Sons, New York.

4. Buhler, D. D., and Hoffman, M. L. 1999. Andersen's Guide to Practical Methods of Propagating Weeds \& Other Plants. A special publication of the Weed Science Society of America. Allen Press, Inc.
5. Cherry, E., and Peet, C. E. 1966. An efficient device for the rapid collection of fungal spores from infected plants. Phytopathology 56:11021103.

6. duPreez, E. D., van Rij, N. C., Lawrence, K. F., Miles, M. R., and Frederick, R. D. 2005. First report of soybean rust caused by Phakopsora pachyrhizi on dry beans in South Africa. Plant Dis. 89:206.

7. Lynch, T. N., Marois, J. J., Wright, D. L., Harmon, C. L., Miles, M. R., and Hartman, G. L. 2006. First report of soybean rust caused by Phakopsora pachyrhizi on Phaseolus spp. in the United States. Plant Dis. 90:970.

8. Melching, J. S., Bromfield, K. R., and Kingsolver, C. H. 1979. Infection, colonization, and urediniospore production on Wayne soybean by four cultures of Phakopsora pachyrhizi, the cause of soybean rust. Phytopathology 69:1262-1265.

9. Melching, J. S., Bromfield, K. R., and Kingsolver, C. H. 1983. The plant pathogen containment facility at Frederick, Maryland. Plant Dis. 67:717-722.

10. Miles, M. R., Frederick, R. D., and Hartman, G. L. 2003. Soybean rust: is the U.S. soybean crop at risk? APSNet feature, June 2003. Online Publication. American Phytopathological Society, St. Paul, MN

11. Miles, M. R., Frederick, R. D., and Hartman, G. L. 2006. Evaluation of soybean germplasm for resistance to Phakopsora pachyrhizi. Plant Health Progress, doi: 10-1094/PHP-20060104-01-RS.

12. Ono, Y., Buritica, P., and Hennen, J. F. 1992. Delimitation of Phakopsora, Physopella and Cerotilium and their species on Leguminosae.
Mycol. Res. 96:825-850.

13. Rytter, J. L., Dowler, W. M., and Bromfield, K. R. 1984. Additional alternative hosts of Phakopsora pachyrhizi, causal organism of soybean rust. Plant Dis. 68:818-819.

14. Saxton, A. M. 1998. A macro for converting mean separation output to letter groupings in Proc Mixed. Pages 1243-1246 in: Proc. 23rd SAS Users Group Int. SAS Institute, Cary, NC.

15. Schneider, R. W., Hollier, C. A., Whitman, H. K., Palm, M. E., McKemy, J. M., Hernandez, J. R., Levy, L., and DeVries-Patterson, R. 2005. First report of soybean rust caused by Phakopsora pachyrhizi in the continental United States. Plant Dis. 89:774.

16. Shah, D. A., and Madden, L. V. 2004. Nonparametric analysis of ordinal data in designed experiments. Phytopathology 94:33-43.

17. Sun, J. H., Li, Z.-C., Jewett, D. K., Britton, K O., Ye, W. H., and Ge, X.-J. 2005. Genetic diversity of Pueraria lobata (kudzu) and closely related taxa as revealed by inter-simple sequence repeat analysis. Eur. Weed Res. Soc. Weed Res. 45:255-260.

18. Susko, D. J., Mueller, J. P., and Spears, J. F. 2001. An evaluation of methods for breaking seed dormancy in kudzu (Pueraria lobata). Can. J. Bot. 79:197-203.

19. Vakili, N. G., and Bromfield, K. R. 1976 Phakopsora rust on soybean and other legumes in Puerto Rico. Plant Dis. Rep. 60:995-999.

20. Yamaoka, Y., Fujiwara, Y., Kakishima, M., Katsuya, K., Yamada, K., and Hagiwara, H. 2002. Pathogenic races of Phakopsora pachyrhizi on soybean and wild host plants collected in Japan. J. Gen. Plant Pathol. 68:52-56. 